\title{
SOIL MESO- AND MACROFAUNA IN TWO SOYBEAN CROPS AFTER SWINE WASTEWATER APPLICATION
}

Doi:http://dx.doi.org/10.1590/1809-4430-Eng.Agric.v37n3p556-564/2017

\section{ANA P. C. MACIEL ${ }^{1}$, SILVIO C. SAMPAIO ${ }^{*}$, MARCELO B. REMOR ${ }^{1}$, DANIELLE M. ROSA ${ }^{1}$, RALPHO R. DOS REIS ${ }^{1}$}

\author{
${ }^{2 *}$ Corresponding author. Grupo de Pesquisa em Ciências Agro-Ambientais, Universidade Estadual do Oeste do Paraná/ \\ Cascavel - PR, Brasil. E-mail: silvio.sampaio@unioeste.br
}

\begin{abstract}
Hog raising generates a large amount of residues that is commonly discarded into the soil as fertilizer even with environmental risks. In this context, the aim of this study was to assess the application effects of different doses of swine wastewater (SW) associated with mineral fertilization on the abundance and diversity of organisms of soil meso- and macrofauna in two soybean crops. Treatments consisted of four doses $\left(0,100,200\right.$, and $\left.300 \mathrm{~m}^{3} \mathrm{ha}^{-1}\right)$ of SW with or without mineral fertilization in two soybean crop, totaling 24 experimental units. Soil meso- and macrofauna were sampled using pitfall traps installed at each plot. Samples were sorted and the organisms were separated and identified. The highest abundances were found between groups of springtails and spider mites. Soil meso- and macrofauna differed between soybean crops influenced by soil physical and chemical parameters. Doses of swine wastewater between 0 and $300 \mathrm{~m}^{3} \mathrm{ha}^{-1}$ and mineral fertilization do not have effects on ecological indices of soil meso- and macrofauna. However, periodic applications over time change soil physicochemical variables, which may lead to negative effects in the long term.
\end{abstract}

KEYWORDS: mineral fertilization, swine wastewater, soil fauna.

\section{INTRODUCTION}

Population growth stimulated livestock expansion due to increased demand for animal protein-based food. However, intensive animal farming generates a considerable amount of residues with high levels of contaminants, which may cause several environmental impacts. These problems are related to a high load of organic matter, micro, and macronutrients (BASSO et al., 2012; FIA et al., 2015). Due to inadequate management, these residues are often released or disposed of in the environment, mainly contaminating water resources and soil.

Swine wastewater reuse as a biofertilizer is an option to dispose of and/or treat the effluent by supplying plants with water and nutrients, reducing the use of natural resources (KESSLER et al., 2013). However, the use of wastewater in large doses may lead to the accumulation of residues in soils (LUCAS et al., 2013), percolated water, leading to the leaching of ions (PRIOR et al., 2009; MAGGI et al., 2011), and in runoff material (WANG et al., 2013), contaminating water resources. Thus, researches on residue physical and chemical properties are essential for planning actions that allow recovering contaminated areas or preserving those non-degraded (DOS REIS et al., 2013).

Soil chemical changes are directly influenced by microbiological activity and soil meso- and macrofauna, which can be changed by the addition of organic effluents as a function of food supply, temperature modification, and soil cover (MOURA et al., 2016; TESSARO et al., 2016). The effects on soil fauna can be positive or negative, varying according to residue composition and management, which are capable of altering the quality and quantity of soil organic matter, the $\mathrm{C} / \mathrm{N}$ ratio, and metal accumulation such as copper and zinc present in high amounts in swine residues (POSTMA-BLAAUW et al., 2012). Therefore, the knowledge of functional groups soil meso- and macrofauna from areas used for swine wastewater management can provide information on the impact generated in the soil from the elimination of one or more soil organisms (BLOUIN et al., 2013).

\footnotetext{
${ }^{1}$ Grupo de Pesquisa em Ciências Agro-Ambientais, Universidade Estadual do Oeste do Paraná/ Cascavel - PR, Brasil. 
Hog raising residues may bring risks to the environment when improperly managed such as damage to soil fauna. However, soil fauna behavior due to organic effluent reuse is still little known. Although studies such as those developed by TESSARO et al. (2011), TESSARO et al. (2013), and PORTILHO et al. (2011) are pioneers and provide valuable answers, they were carried out during only one crop cycle. Thus, the aim of this study was to assess the application effects of swine wastewater (SW) doses associated with mineral fertilization (MF) on the community structure of organisms present in soil meso- and macrofauna in two soybean crops.

\section{MATERIAL AND METHODS}

The experiment was carried out from October 2010 to March 2011 (crop 1) and from November 2011 to March 2012 (crop 2), the periods indicated for soybean cultivation. The experimental design used was a $4 \times 2$ factorial randomized block design with three replications, totaling 24 sample units. Randomization followed the order established by PRIOR et al. (2009), maintaining the application rate history of SW and MF in the area. Treatments with the respective factor levels are shown in Table 1. Unit samples consisted of drainage lysimeters with an area of 1.0 $\mathrm{m}^{2}$, a depth of $1.1 \mathrm{~m}$, and a spacing of $0.5 \mathrm{~m}$.

TABLE 1. Description of treatments and chemical characterization of swine wastewater.

\begin{tabular}{|c|c|c|c|c|}
\hline \multirow{2}{*}{$\mathrm{MF}$} & \multicolumn{4}{|c|}{ SW doses $\left(\mathrm{m}^{3} \mathrm{ha}^{-1}\right)$} \\
\hline & 0 & 100 & 200 & 300 \\
\hline Absence (A) & SW0-MFA & SW100-MFA & SW200-MFA & SW300-MFA \\
\hline Presence $(\mathrm{P})$ & SW0-MFP & SW100-MFP & SW200-MFP & SW300-MFP \\
\hline \multicolumn{5}{|c|}{ SW chemical characteristics } \\
\hline \multirow{2}{*}{\multicolumn{3}{|c|}{ Parameter $\left(\mathrm{mg} \mathrm{L}^{-1}\right)$}} & \multicolumn{2}{|c|}{ Soybean crop season } \\
\hline & & & 2010-2011 & 2011-2012 \\
\hline \multicolumn{3}{|c|}{ Total organic carbon ${ }^{1}$} & 684.80 & 2916.30 \\
\hline \multicolumn{3}{|c|}{ Total nitrogen ${ }^{2}$} & 481.70 & 707.00 \\
\hline \multicolumn{3}{|c|}{ Total phosphorus ${ }^{3}$} & 22.06 & 33.01 \\
\hline \multicolumn{3}{|c|}{ Potassium $^{4}$} & 8.95 & 265.00 \\
\hline \multicolumn{3}{|c|}{ Sodium $^{4}$} & 36.70 & 16.80 \\
\hline \multicolumn{3}{|c|}{ Calcium $^{4}$} & 52.87 & 236.00 \\
\hline \multicolumn{3}{|c|}{ Magnesium ${ }^{4}$} & 67.70 & 67.00 \\
\hline \multicolumn{3}{|c|}{ Copper $^{4}$} & 1.86 & 8.30 \\
\hline \multicolumn{3}{|c|}{ Zinc $^{4}$} & 10.22 & 39.00 \\
\hline \multicolumn{3}{|c|}{ Iron $^{4}$} & 8.95 & 27.40 \\
\hline \multicolumn{3}{|c|}{ Manganese $^{4}$} & 2.68 & 7.10 \\
\hline \multicolumn{3}{|c|}{ Total solids ${ }^{5}$} & 3498.30 & 20000.00 \\
\hline \multicolumn{3}{|c|}{ Fixed solids ${ }^{5}$} & 1310.80 & 2300.00 \\
\hline \multicolumn{3}{|c|}{ Volatile solids $^{5}$} & 2187.50 & 17700.00 \\
\hline
\end{tabular}

SW: Swine wastewater; MF: Mineral fertilization; ${ }^{1} \mathrm{TOC} ;{ }^{2}$ Micro-Kjeldahl; ${ }^{3}$ Visible spectrophotometer; ${ }^{4}$ Flame atomic absorption spectrophotometer; ${ }^{5}$ Gravimetric method.

The soil of each lysimeter was collected before SW application and after soybean harvest for 
both crops for physicochemical characterization. SW used in the experiment was collected from an integrated biosystem of swine residue treatment in the district of Três Bocas, Toledo, PR, Brazil. SW was applied in doses pre-established by PRIOR (2009) throughout the lysimeter area. SW was collected the day before the treatment application and was characterized chemically considering the following parameters: $\mathrm{pH}$, electrical conductivity (EC), total solids (TS), total fixed solids (TFS), total volatile solids (TVS), total nitrogen (N), nitrate + nitrite $\left(\mathrm{NO}_{3}{ }^{-}+\mathrm{NO}_{2}{ }^{-}\right)$, ammoniacal nitrogen, total phosphorus $(\mathrm{P})$, potassium $\left(\mathrm{K}^{+}\right)$, sodium $\left(\mathrm{Na}^{+}\right)$, calcium $\left(\mathrm{Ca}^{+2}\right)$, magnesium $\left(\mathrm{Mg}^{+2}\right)$, copper $\left(\mathrm{Cu}^{+2}\right)$, zinc $\left(\mathrm{Zn}^{+2}\right), \mathrm{BOD}$, and COD.

Soybean sowing was carried out two days after SW application under the no-tillage system at each lysimeter, with spacing between lines and plants as recommended for this crop. MF was performed in the furrow sowing with mineral fertilizer at a dose of $250 \mathrm{~kg} \mathrm{ha}^{-1}$ using the fertilizer formulation 0-20-20, providing $25 \mathrm{~kg} \mathrm{ha}^{-1}$ of $\mathrm{P}_{2} \mathrm{O}_{5}$ and $\mathrm{K}_{2} \mathrm{O}$ for the crop. Cultural treatments were performed at all treatments using the recommended products and dosages when pests attacked the crop.

Soil meso- and macrofauna were sampled using pitfall traps installed individually at each lysimeter. Two collections were carried out during each soybean crops at the early (V2) and intermediate (R2) soybean growth stages. Traps were activated for seven days at each collection period. After this period, traps were removed and washed for the total preservative solution (4\% formalin) removal. Each container's contents were poured into a $100-\mu \mathrm{m}$ mesh sieve. The specimens were stored in bottles containing $70 \%$ alcohol solution for later identification. Identification process was carried out at the level of taxonomic order using a stereoscopic microscope and dichotomous classification keys (GALLO et al., 2002; AQUINO et al., 2006). Weather data of temperature, humidity, and precipitation during the collection periods were provided by the Paraná State Meteorological System (SIMEPAR), as shown in Figure 1.

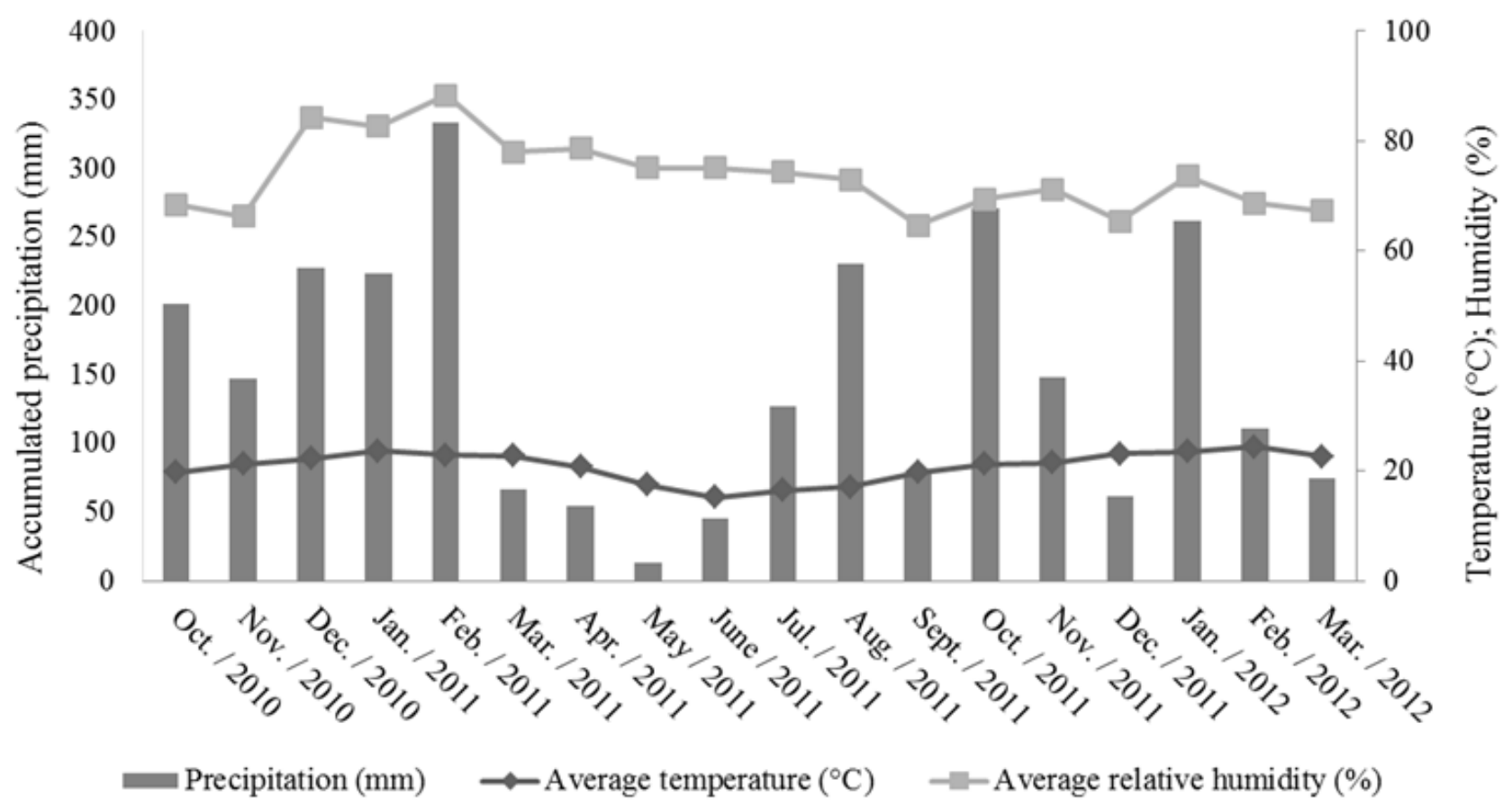

FIGURE 1. Data of total precipitation and averages of humidity and air temperature in the soybean crop seasons of 2010-2011 and 2011-2012.

Ecological indices (number of taxa, number of individuals, dominance, Simpson's diversity, Shannon's diversity, Buzas and Gibson's uniformity, Brillouin index, Menhinick's richness, Margalef's richness, equitability, Fisher's alpha diversity, Berger-Parker dominance, and Chao1 richness) of soil meso- and macrofauna related to each treatment was calculated by means of the software PAST 3.07 (HAMMER et al., 2001). The set of ecological variables of treatments was 
summarized in a single Principal Component Analysis (PCA) by using the software PC-ORD 4.0 (McCUNE \& MEFFORD, 1999). This analysis reduces the set of original variables in a set of Principal Components (PCs), which seeks to maintain the maximum variability of the original set. PCA was performed on the Pearson correlation matrix of variables and the criterion for retaining PCs adopted was the broken-stick, i.e. with eigenvalues higher than expected at random (JACKSON, 1993). In order to interpret the meaning of retained PCs of original variables, only Pearson correlation coefficients higher than $70 \%$ were considered (JOLLIFFE, 1986). In addition, PCA graph was constructed only with the centroids of each treatment to reduce visual pollution and facilitate visualization.

PCs validated by the broken-stick criterion were submitted to the two-factorial permutationbased multivariate analysis of variance (Per-MANOVA) using 9999 permutations and the Euclidean distance measure at 5\% significance level to verify a significant statistical difference between collection points and between hydrological stations. Per-MANOVA is a non-parametric correspondent of MANOVA with the difference that the p-value is calculated by permutation of results between treatments (ANDERSON, 2001). Per-MANOVA was performed in an $8^{1} \times 2^{1}$ scheme with the first factor as treatments (Table 1) and the second factor as soybean crops (20102011 and 2011-2012).

The canonical correspondence analysis (CCA) (TER BRAAK, 1986) was used to infer on the influences of soil physicochemical variables in soil meso- and macrofauna community. In the case of structuring and correlation of taxa to the environment, both significantly higher than those expected at random by the Monte Carlo test with 9998 randomizations $(\mathrm{p}<0.05)$, CCA ordering was performed and the influence of each soil physical and chemical variable was inferred by means of the canonical correlation coefficient. In order to reduce visual pollution and facilitate visualization, CCA graph was constructed only with the centroids of each treatment.

\section{RESULTS AND DISCUSSION}

In the first soybean crop (2010-2011), 11,543 organisms were found at the soybean growth stage V2 and 7,761 organisms at the stage R2, totaling 19,304 organisms. In the second soybean crop (2011-2012), 23,094 organisms were found at the soybean growth stage V2 and 3,166 organisms at the stage R2, totaling 26,264. During both crops, 45,564 organisms of soil meso- and macrofauna were collected distributed among the orders Collembola, Hymenoptera, Hemiptera, Coleoptera, Diptera, Orthoptera, Araneae, Thysanoptera, Diplopoda, Oribatida, Mesostigmata, Prostigmata, and Astigmata. The number of individuals collected over this study was much higher than that collected in the study conducted by CASTALDELLI et al. (2015), who collected 15,424 organisms, demonstrating the robustness and representativeness of sampling performed in this study.

PCA of ecological indices of each treatment is shown in Figure 2. Two PCs were considered as adequate to be assessed according to the broken-stick criterion, totaling $86.04 \%$ of the data set variability. PCA demonstrated that the variability of ecological indices between soybean crops (2010-2011 and 2011-2012) is higher than the variability between treatments (Figure 2). The greater variability of ecological indices between crops is due to weather conditions before sowing and during cultivation and collection periods. According to ALMEIDA et al. (2013), some groups of soil meso- and macrofauna present higher incidence during wet periods. In addition, water is a limiting factor for soil fauna behavior, presenting a direct relationship with temperature, precipitation, and humidity. However, some groups may be negatively influenced by high humidity due to changes in the availability of resources (CASTALDELLI et al., 2015).

Another contributing factor is the change in soil physical and chemical characteristics caused by periodic SW application (TESSARO et al., 2016). Between both soybean crops, two SW applications were carried out in the sample area for corn and black oat cultivation, respectively. In addition, the area has a six-year SW application history and in general three applications per year. 


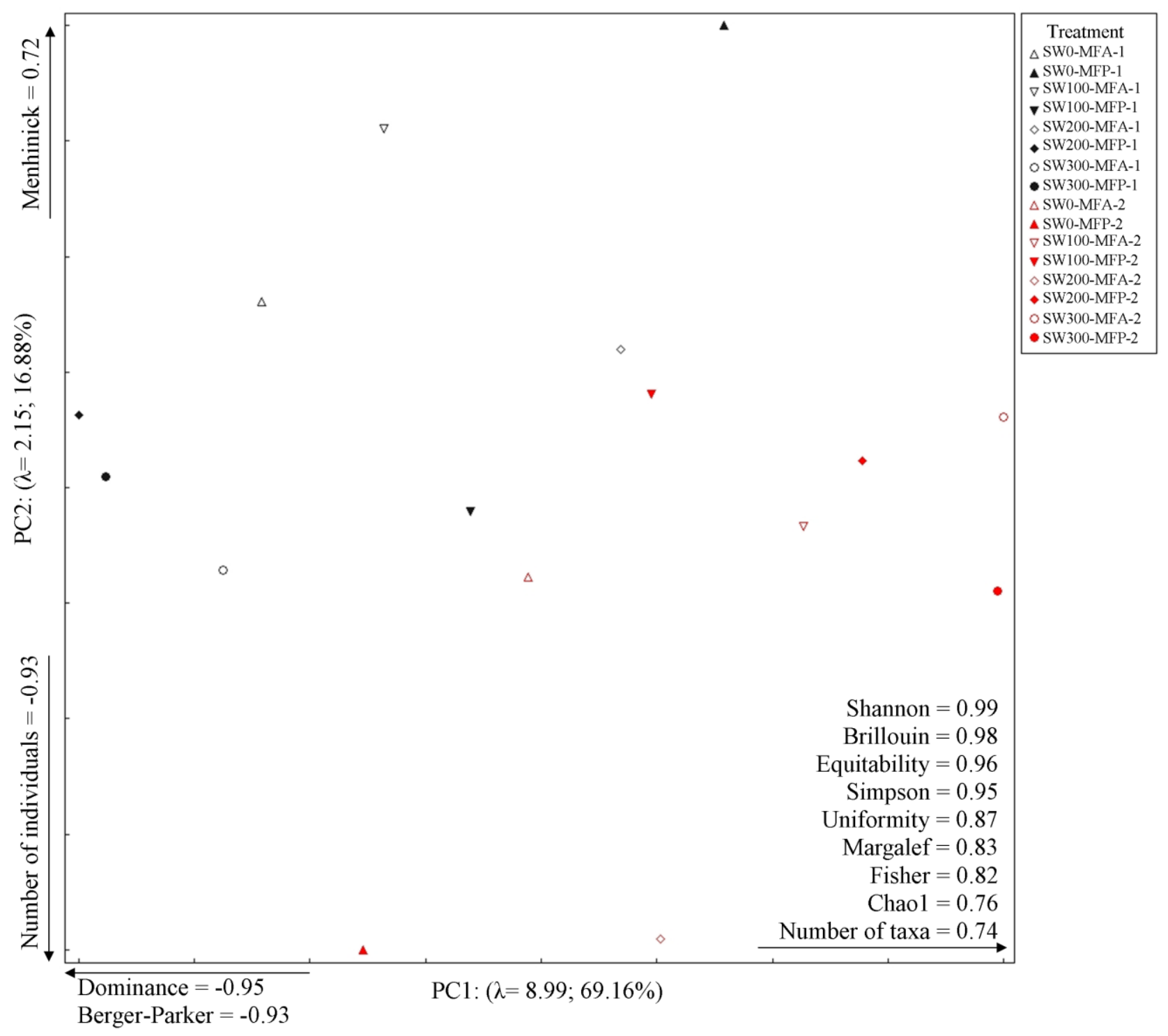

FIGURE 2. Principal component analysis of ecological indices obtained at each treatment.

PC1 is composed by Simpson's diversity, Shannon's diversity, Buzz and Gibson's uniformity, Brillouin index, Margalef's richness, equitability, Fisher's alpha diversity, Chaol richness, and number of taxa in the positive quadrant, and by the variables dominance and Berger-Parker dominance in the negative quadrant (Figure 2). The ecological indices that were grouped together in the positive quadrant of PC1 indicate ecological stability (STENGER-KOVÁCS et al., 2016), being assumed that these indices have a positive correlation with each other. However, the indices that were grouped together in the negative quadrant of PC1 indicate ecological instability (STENGERKOVÁCS et al., 2016), showing a negative correlation with the indices located in the positive quadrant of $\mathrm{PC} 1$.

In addition, PC1 demonstrates that the 2011-2012 crop season presented a higher Simpson's diversity, Shannon's diversity, Buzas and Gibson's uniformity, Brillouin index, Margalef's richness, equitability, Fisher's alpha diversity, and Chao1 richness. These indices show a greater ecological balance during the sampled period. On the other hand, the 2010-2011 crop season showed a higher dominance and Berger-Parker dominance, with an ecological instability in soil meso- and macrofauna. Values of dominance index and Berger-Parker dominance were influenced mainly by the order Collembola in both soybean crops.

The dominance of the order Collembola was reported in studies conducted by TESSARO et al. (2013) and CASTALDELLI et al. (2006). In these studies, the authors assessed the application of different doses of SW $\left(0,100,200\right.$, and $\left.300 \mathrm{~m}^{3} \mathrm{ha}^{-1}\right)$ in plots cultivated with corn, oat, and 
soybean, in addition to a plot of native vegetation and another with only mineral fertilizers. The high occurrence of the order Collembola is related to food habit because these animals feed mainly on fungi associated with the crop straw despite being normally abundant in the litter (BLOUIN et al., 2013; SIDDIKY et al., 2012).

PC2 was composed of the variable number of individuals in the negative quadrant and the Menhinick's richness in the positive quadrant. Based on PC2, the 2011-2012 crop season presented the highest number of individuals collected.

The two-factorial Per-MANOVA (Table 2) with a significance of 5\% confirms PCA (Figure 2 ), showing that the ecological indices presented statistical differences only between crops ( $\mathrm{p}$-value $=0.0082)$. Therefore, SW doses applied $\left(0,100,200\right.$, and $\left.300 \mathrm{~m}^{3} \mathrm{ha}^{-1}\right)$ do not have significant effects on ecological indices of soil meso- and macrofauna. SEGAT et al. (2015) did not find toxic effects of SW on bioindicators in soils with high clay and organic matter concentrations since these soils have a higher negative charge, which increases the cation adsorption, making the metals unavailable for soil solution. Because this experiment was conducted in a clayey Oxisol (GONCALVES et al., 2012; SANTOS et al., 2015), higher doses than those studied are required (>300 $\mathrm{m}^{3} \mathrm{ha}^{-1}$ ) so that toxic compounds (heavy metals) are available to influence soil meso- and macrofauna.

TABLE 2. Two-factorial Per-MANOVA for swine wastewater and soybean crop with 4999 permutations on the ecological indices of soil meso- and macrofauna obtained in the 2010-2011 and 2011-2012 crop seasons.

\begin{tabular}{llllll}
\hline Source of variation & DF. & SS & MS & F & p-value \\
\hline SW & 7 & 0.22575 & $0.3225 \mathrm{E}-01$ & 1.0869 & 0.3966 \\
Crop & 1 & 0.21398 & 0.21398 & 7.2115 & 0.0082 \\
SW $\times$ Crop & 7 & 0.36370 & $0.5196 \mathrm{E}-01$ & 1.7511 & 0.1244 \\
Residual & 32 & 0.94850 & $0.2967 \mathrm{E}-01$ & & \\
Total & 47 & 1.7529 & & & \\
\hline
\end{tabular}

$\mathrm{DF}$ - degrees of freedom; SS - sum of squares; MS - mean square; SW - swine wastewater; $\mathrm{SW} \times \mathrm{Crop}$ - interaction between $\mathrm{SW}$ and Crop.

CCA between treatments and values of soil physicochemical variables is shown in Figure 3A. According to the Monte Carlo test, with only 5\% significance, only the axis 1 (CC1, explanation of $43 \%$, p-value $=0.01$ ) can be assessed. $\mathrm{CC} 1$ confirms the results obtained by PCA (Figure 2) and PerMANOVA (Table 2), demonstrating that the variability between crops is higher than the variability between treatments. However, it also confirms that the difference between crops was caused by changes in soil physicochemical composition. In the 2010-2011 crop season, soil showed higher values of organic matter (OM), Mg, sum of bases (SB), and cation exchange capacity (CEC) whereas in the 2011-2012 crop season, soil presented higher values of organic N (Norg), base saturation (BS), and $\mathrm{NO}_{3}+\mathrm{NO}_{2}$. Therefore, comparing these results with PCA, the ecological indices that represent the stability of soil meso- and macrofauna with diversity, equitability, uniformity, among others, are influenced by the physicochemical variables Norg, $\mathrm{BS}$, and $\mathrm{NO}_{3}+$ $\mathrm{NO}_{2}$. 

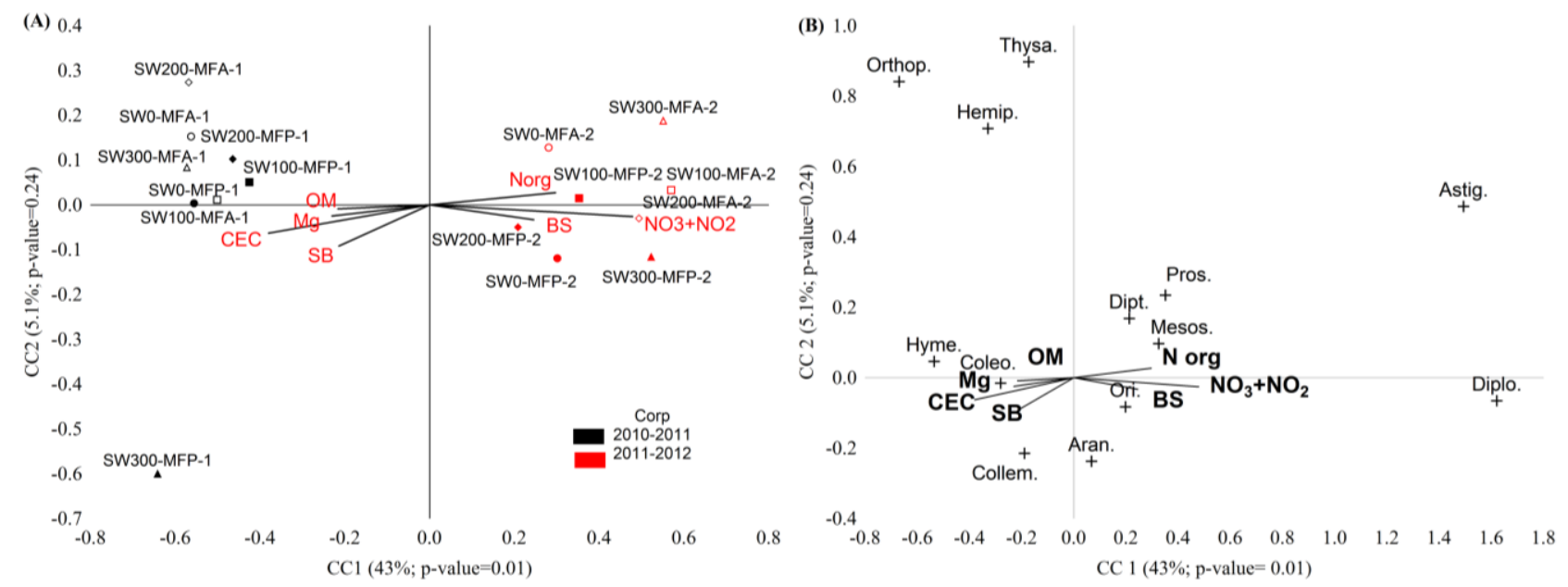

FIGURE 3. Ordering of experimental units obtained in the 2010-2011 and 2011-2012 soybean crops for the composition of soil meso- and macrofauna community as a function of physicochemical variables using linear combinations of these variables (arrow size is proportional to the variable effect) (Figure 3A). Composition of soil meso- and macrofauna community according to physicochemical variables defined by the Canonical Correlation Analysis (Figure 3B).

In addition, CCA between orders of soil meso- and macrofauna and values of soil physicochemical variables (Figure 3B) shows that the orders Orthoptera, Hymenoptera, Coleoptera, and Collembola presented a positive correlation with $\mathrm{OM}, \mathrm{Mg}, \mathrm{SB}$, and CEC whereas the orders Astigmata, Diplopoda, Prostigmata, and Mesostigmata presented a positive correlation with Norg, $\mathrm{BS}$, and $\mathrm{NO}_{3}+\mathrm{NO}_{2}$. The higher number of individuals from the orders Astigmata and Diplopoda in the 2011-2012 crop season reduced the dominance of the order Collembola by increasing the values of diversity, equitability, and uniformity indices (Figure 2). ZHU \& ZHU (2015) and WANG et al. (2015) also observed the orders Collembola and Coleoptera positively correlated with OM and Prostigmata, Diplopoda, and Mesostigmata positively correlated with total nitrogen concentration. Thysanoptera, Diptera, Oribatida, and Araneae showed no correlation with any soil physicochemical variable, demonstrating that these orders were distributed equally between treatments and crops.

Soil meso- and macrofauna has a great mobility, which may have influenced some results since sample units have an area of $1 \mathrm{~m}^{2}$, in addition to being close to each other. This fact may have influenced the quantification of individuals since the migration rate from one sample unit to another was not measured.

\section{CONCLUSIONS}

Doses of swine wastewater between 0 and $300 \mathrm{~m}^{3} \mathrm{ha}^{-1}$ associated with mineral fertilization do not present effects on ecological indices of soil meso- and macrofauna. Therefore, these doses do not present perceptible ecotoxicological effects to organisms. However, periodic applications over time change soil physicochemical variables, which influence soil community composition and may lead to negative effects in the long term.

\section{REFERENCES}

ALMEIDA, M.A.X.; SOUTO, J.S.; SOUTO, P.C. Composição e sazonalidade da mesofauna do solo do semiárido paraibano. Revista Verde de Agroecologia e Desenvolvimento Sustentável, Mossoró, v.8, n.4, p.214-222, 2013.

ANDERSON, M. J. A new method for non-parametric multivariate analysis of variance.Austral Ecology, Carlton, v.26, p.32-46, 2001. 
AQUINO, A. M.; MENEZES, E. L. A.; QUEIROZ, J. M. Recomendações para a coleta de artrópodes terrestres por armadilhas de queda (Pitfall traps). Seropédica: Embrapa Agrobiologia, 2006. (Circular técnica 18). Disponível em:

<http://www.cnpab.embrapa.br/publicacoes/download/cit018.pdf>. Acesso em: 19 out. 2010.

BASSO, C. J.; CERETTA, C. A.; FLORES, É. M. M.; GIROTTO, E. Teores totais de metais pesados no solo após aplicação de dejeto líquido de suínos. Ciência Rural, Santa Maria, v.42, n.4, p.653-659, 2012.

BLOUIN, M.; HODSON, M.E.; DELGADO, E.A.; BAKER, G.; BRUSSAARD, L.; BUTT, K.R.; DAI, J.; DENDOOVEN, L.; PERES, G.; TONDOH, J.E.; CLUZEAU, D.; BRUN, J.J. A review of earthworm impact on soil function and ecosystem services. European Journal of Soil Science, Oxford, v.64, p.161-182, 2013.

CASTALDELLI, A. P. A.; SAMPAIO, S.C.; TESSARO, D.; HERRMANN, D.R.; SORACE, M. Meso e macrofauna de solo cultivado com milho e irrigado com água residuária da suinocultura. Engenharia Agrícola, Jaboticabal, v.35, n.5, p.905-917. 2015.

DOS REIS, R.R.; SAMPAIO, S.C.; DE MELO, E.B. The effect of different log P algorithms on the modelling of the soil sorption coefficient of nonionic pesticides.Water Research, Oxford, v.47, n.15, p. 5751-5759, 2013.

FIA, F.R.L.; MATOS, A.T.; FIA, R; BORGES, A.C.; ABREU, E.C. Influência da carga de nutrientes e da espécie cultivada na remoção de $\mathrm{K}, \mathrm{Na}, \mathrm{Cu}$ e $\mathrm{Zn}$ da água residuária da suinocultura tratada em sistemas alagados construídos. Revista Ambiente e Água, Taubaté, v.10, n.3, p. 542$553,2015$.

GALLO, D.; NAKANO, O.; NETO, S. S.; CARVALHO, R. P. L.; BATISTA, G. C. D.; BERTI FILHO, E.; PARRA, J. R. P. L.; ZUCCHI, R. A.; BAT, S. Entomologia Agrícola. São Paulo: Editora Agronômica Ceres, 2002. 920p.

GONÇALVES, M.S.; SAMPAIO, S.C.; COELHO, S.R.M.; SUSZEK, F.L.; CORDOVIL, C.M.S. Atrazine bound residues formation and dissipation in subtropical soil under swine wastewater application. Engenharia Agrícola, Jaboticabal, v.32, n.6, p.1156-1164, 2012.

HAMMER, Ø.; HARPER, D.A.T.; RYAN, P. D. PAST: Paleontological Statistics Software Package for Education and Data Analysis. Palaeontologia Electronica, College Station, v.4, n.1, p.1-9, 2001.

JACKSON, D.A. Stopping Rules in Principal Components Analysis: A comparison of heuristical and statistical approaches. Ecology, New York, v.74, p.2204-2214, 1993.

JOLLIFFE, I.T. Principal component analysis. New York: Springer-Verlag, 1986.

KESSLER, N. C. H; SAMPAIO, S. C.; LUCAS, S. D.; SORACE, M; CITOLIN, A. C. Swine wastewater associated with mineral fertilization in soybean (Glycine max L.) cultures: 9th production cycle. Journal of Food, Agriculture \& Environment, Helsinki, v.11, p.936-942, 2013.

LUCAS, S. D. M.; SAMPAIO, S. C.; URIBE-OPAZO, M. A.; GOMES, S. D.; KESSLER, N. C. H.; PRADO, N. V. Long-term behavior of $\mathrm{Cu}$ and $\mathrm{Zn}$ in soil and leachate of an intensive no-tillage system under swine wastewater and mineral fertilization. African Journal of Agricultural Research, Nairobi, v.8, n.7, p.639-647, 2013.

MAGGI, C. F.; FREITAS, C. L. F.; SAMPAIO, S. C.; DIETER, J. Lixiviação de nutrientes em solo cultivado com aplicação de água residuária de suinocultura. Revista Brasileira de Engenharia Agrícola e Ambiental, Campina Grande, v.15, p.170-177, 2011.

McCUNE, B.; MEFFORD, M. J. Multivariate analysis on the PC-ORD system.Version 4.MjM Software. Gleneden Beach, Oregon. 1999. 
MOURA, A.C.; SAMPAIO, S.C.; REMOR, M.B.; SILVA, A.P.; PEREIRA, P.A.M. Long-term effects of swine wastewater and mineral fertilizer association on soil microbiota. Engenharia. Agrícola, Jaboticabal, v.36, p.318-328, 2016.

PORTILHO, I.I.R; CREPALDI, R.A.; BORGES, C.D.; SILVA, R.F.; SALTON, J.C.; MERCANTE, F.M. Fauna invertebrada e atributos físicos e químicos do solo em sistemas de integração lavoura-pecuária. Pesquisa Agropecuária Brasileira, Brasília, DF, v.46, n.10, p.13101320,2011

POSTMA-BLAAUW, M.B.; GOEDE, R.G.M.; BLOEM, J.; FABER, J.H.; BRUSSAARD, L. 2012. Agricultural intensification and de-intensification differentially affect taxonomic diversity of predatory mites, earthworms, enchytraeids, nematodes and bacteria. Applied Soil Ecology, New York, v.57, p.39-49, 2012.

PRIOR, M.; SMANHOTTO, A.; SAMPAIO, S. C.; NÓBREGA, L. H. P.; OPAZO, M. A. U.; DIETER, J. Acúmulo e percolação de fósforo no solo devido a aplicação de água residuária da suinocultura na cultura do milho (Zea mays L.). Pesquisa Aplicada e Agrotecnologia, Guarapuava, v.2, p.89-96, 2009.

SANTOS, D.; SOUZA, E.G.; NÓBREGA, L.H.P.; BAZZI, C. L.; QUEIROZ, F.N. Physical properties of soils and soybean yields after planting cover crops. Engenharia Agrícola, Jaboticabal, v.35, n.2, p.280-292, 2015.

SEGAT, J.C.; ALVES,P.R.L.; BARETTA, D.; CARDOSO, E.J.B.N. Ecotoxicological evaluation of swine manure disposal on tropical soils in Brazil. Ecotoxicology and Environmental Safety, New York, v.122, p.91-97, 2015.

SIDDIKY, M.R.K.; KOHLER, J.; COSME, M.; RILLIG, M.C. Soil biota effects on soil structure: Interactions between arbuscular mycorrhizal fungal mycelium and collembolan. Soil Biology and Biochemistry, Oxford, v.50, p.33-39, 2012.

STENGER-KOVÁCS, C.; HAJNAL, É.; LENGYEL, E.; BUCZKÓ, K.; PADISÁK, J. A test of traditional diversity measures and taxonomic distinctness indices on benthic diatoms of soda pans in the Carpathian basin. Ecological Indicators, Amsterdam, v.64, p.1-8, 2016.

TER BRAAK, C. J. F. Canonical correspondence analysis: a new eigenvector technique for multivariate direct gradient analysis. Ecology, New York, v.67, p.1167-1179, 1986.

TESSARO, D. DIETER, J.; CORDOVIL, C. S. C. M. S.; VARENNES, A.; PANSERA, W. A. Macrofauna of soil cultivated with babycorn treated with Swine wastewater combined with chemical fertilization. African Journal of Agricultural Research, Nairobi, v.8, p.86-92, 2013.

TESSARO, D.; SAMPAIO, S. C.; ALVES, L. F. A.; DIETER, J.; CORDOVIL, C. S. C. M. S.; VARENNES, A. Edaphic mesofauna (springtails and mites) in soil cultivated with baby corn and treated with swine wastewater combined with chemical fertilization. International Journal of Food, Agriculture and Environment, Helsinki, v.9, p.983-987, 2011.

TESSARO, D.; SAMPAIO, S.C.; CASTALDELLI, A.P.A. Wastewater use in agriculture and potential effects on meso and macrofauna soil. Ciência Rural, Santa Maria, v.46, n.6, p.976-983, 2016.

WANG, S.; TAN, Y.; FAN, H.; RUAN, H.; ZHENG, A. Responses of soil microarthropods to inorganic and organic fertilizers in a poplar plantation in a coastal area of eastern China. Applied Soil Ecology, New York, v.89, p.69-75, 2015.

WANG, W.; LIANG, T.; WANG, L.; LIU, Y.; WANG, Y.; ZHANG, C.The effects of fertilizer applications on runoff loss of phosphorus.Environmental Earth Sciences, Berlin, v.68, p.13131319, 2013.

ZHU, X.; ZHU, B. Diversity and abundance of soil fauna as influenced by long-term fertilization in cropland of purple soil. Soil \& Tillage Research, New York, v.146, p.39-46, 2015. 